Studia i Materiały, 1/2016 (20): 136-144 ISSN 1733-9758, () Wydział Zarządzania UW DOI 10.7172/1733-9758.2016.20.10

\title{
Gender Differences in Leadership
}

\author{
Anna Górska*
}

The following study presents preliminary research into leadership differences between men and women. This research study is preliminary in character and is intended to initiate a discussion on the impact of gender as a factor in leadership style. Data analysis from a pilot study suggests that differences do exist, but does not provide information as to their source. Further research is needed to answer that question.

Keywords: leadership, gender, differences.

Submitted: 03.03.2016 | Accepted: 27.07.2016

\section{Różnice w zarządzaniu między kobietami a mężczyznami}

Poniższa praca przedstawia badania dotyczace możliwych różnic $w$ sposobie przywództwa między kobietami a mężczyznami. Badanie ma charakter wstępny i ma na celu zainicjowanie dyskusji na temat wptywu ptci jako czynnika wptywajacego na przywództwo. Analiza danych z badania pilotażowego sugeruje, że różnice istnieja, natomiast nie odpowiada na pytanie co jest ich źródtem. Aby odpowiedzieć na to pytanie, konieczne sa dalsze badania.

Słowa kluczowe: zarządzanie, różnice, płeć.

Nadesłany: 03.03.2016 | Zaakceptowany do druku: 27.07.2016

JEL: M12, J16

\section{The General Question}

Are women leading in a way that is different than men?

\section{Hypothesis:}

Hypothesis A: Men and women lead in a different way.

Hypothesis B: Men and women adopt different leadership styles.

Hypothesis C: Men tend to be more task oriented compared to women.

Hypothesis D: Women tend to be more relationship oriented compared to men.

Anna Górska - Kozmiński University.

Mailing address: Kozminski University, 57/59 Jagiellońska St., 03-301 Warsaw; e-mail: ania.maria. gorska@gmail.com.

The creation of the English-language version of these publications is financed in the framework of contract No. 768/P-DUN/2016 by the Ministry of Science and Higher Education committed Republic of Poland to activities aimed at the promotion of education. 


\section{Introduction}

Women are still underrepresented in managerial positions, despite of the $6.3 \%$ increase in employment over the last six years. In Poland, $48 \%$ of women are employed, but only $10 \%$ work in managerial positions (GUS, Kobiety i mężczyźn na rynku pracy, 2012) and as few as $4 \%$ sit on the managerial boards of the 500 largest companies in Poland. Additionally, their earnings are lower by $20 \%$ as compared to those of men. In contrast to Denmark these results are poor. There, women occupy $23 \%$ of all managerial positions and over $70 \%$ of women have jobs (European Commission, 2013). Such low numbers of women in managerial position may be caused by the belief that men are better leaders than women, as men embody masculine characteristics, including power and control, which used to be considered the traits of a good leader.

Due to such a low presence of women in managerial positions, companies loose an opportunity to benefit from a diversified managerial team. Therefore, this paper is intended to initiate a discussion whether the underrepresentation of women in leadership positions is due to the fact that women and men lead in different ways.

The goal of the current study is to determine whether gender differences exist in leadership and their potential source. A literature analysis, supported by an interview with an expert and a pilot study, was conducted in order to present the topic from various angles.

\section{Defining Leadership}

Leadership means being in charge of other people in numerous ways, including motivation, organization, and the inspiration of followers. A manager has formal power over subordinates, which is not necessarily true in the case of a leader (Eagly and Carli, 2003). Scholars distinguish between leadership and management by describing managers as those responsible for formal organization and control work. Leaders are defined as those who set new directions, inspire people, and adapt to changes. For the purposes of this article, the terms leader and manager are used interchangeably when discussing organizational leadership, as both activities are intertwined in the organization (Eagly and Carli, 2003).

Leadership is not a position. Leadership is an attitude as well as action. It can be most suitably described as the process of influencing in which one person can support others in the accomplishment of a common goal (Chemers, 1997). There continues to be an ongoing discussion a to whether leaders are "born" or "made."

In the 19th century leaders were believed to inherit their qualities, skills, and traits from their ancestors. Thus, the "great men" theory was especially popular among people from the upper classes (Kirkpatrick and Locke, 1991). In the 20th century, trait theory evolved into one making no distinction as to whether characteristics were inherited or acquired. In the mid-20th century Ralph Stogdill found that individuals do not become leaders through mere possession of certain traits. He found that situational factors may become influential as well. Thus, Stogdill believed that there are people that will more likely become leaders than others, but only when in an appropriate situation (Stogdill, 1948). In 2011 Northouse, after thorough research on the traits theory, found that traits actually may be helpful in becoming a successful leader, but that they do not predetermine whether an individual will become one (Northouse, 2011).

The trait approach to leadership is necessary when evaluating differences between male and female leaders as it assumes that there exist certain common traits among leaders, and for this reason there are also different traits common to men and women leaders. Apart from this trait-based approach, other approaches have been developed in the 20th century, including behavioral, situational, relational, and "new leadership" approaches. A theory, developed by Kurt Lewin, has also influenced modern knowledge about leaders. This theory states that there are three styles of leadership: authoritarian, democratic, and laissez-faire (Lewin, 1939). The authoritarian leadership style keeps strict and close control over followers through monitoring, regulations, and standardization. The democratic leadership style consists of a leader who shares decision-making abilities with team members by promoting interest and social equality. A laissez-faire leader delegates tasks to followers providing little 
direction and often no supervision. There was a study conducted in 1939 by a group of psychologists led by the inventor of the theory. It proved that people tend to work differently under each of the leadership styles (Lewin, 1939), where the democratic approach tends to be most appropriate and effective.

Veithzal Rival (2008) argued that leadership style is "a set of leadership traits used to influence subordinates in order to achieve organizational goals or it can also be said that the style of leadership is a pattern of behavior and preferred strategy and is often applied by a leader." Similarly, Miftah Thoha (2007) states that leadership style is a behavior set used by an individual when trying to influence others (Usman et al., 2016). The Path-Goal Theory of Leadership identifies four leadership styles: directive, supportive, participative, and achievement-oriented (Usman et al., 2016). The theory corresponds with the Lewin divisions, where directive is similar to autocratic, while supportive and participative resemble to democratic leadership style.

\section{Gender Differences in Leadership}

Gender affects leadership in many aspects. Whether men and women lead in a different way is still a highly debated issue. However, the major effect of gender on leadership is that women are presumed to be less competent and less worthy to hold leadership positions (Eagly, 2001).

Leadership style depends on a number of factors, where gender is one of them. Leaders adapt to expectations based on people's categorization of them as male or female (Eagly and Johannesen-Schmidt, 2001). Those expectancies are derived from traditional gender roles - roles in the society, in the family, and in paid employment (Eagly et al., 2000).

Dr. Alice Eagly's research from the 1980s and 1990s proves that women in managerial positions adopt the participative and democratic styles of leadership and act more as transformational leaders than men, who adopted a more transactional style of leadership. According to Dr. Eagly's research, female managers tended to greater stress on communication, affiliation, and cooperation than men. Moreover, women had a more collective approach (Andersen and Hansson, 2011). Women intuitively notice which employees need more support and show more understanding (Kupczyk, 2009). Additionally, it has been found that women are more relationship oriented when compared to men, who are task oriented. The study was repeated in 2001 by Eagly and Johannesen-Schmidt. Results and conclusions remained unchanged (Eagly and Johannesen-Schmidt, 2001). A contradictive study indicates that the only difference between male and female leadership lies in the decision-making process, while differences in other areas such as task orientation, motivation, and leadership styles are not significant enough to warrant any statement that leadership varies between genders (Andersen and Hansson, 2011). Moreover, research by Kent and Schuele has proven no distinction when it comes to transformational and transactional leadership between male and female leaders (Kent and Schuele, 2010).

In accordance to organizational behavior theories, men and women who occupy the same leadership role would behave similarly (Kanter, 1977). In reality, gender roles influence behavior causing differences in the behavior of female leaders and male leaders (Eagly and Johannesen-Schmidt, 2001). Accordingly, Gutek and Morasch (1982) maintained that gender role does affect the organization and creates a "background" identity in the workplace (Ridgeway, 1997). Research by Alice Eagly (2000) suggests that even though some gender-stereotypic differences diminish under the influence of organizational role, others do not.

It is difficult to evaluate exactly to what extent gender affects how people lead, but the fact that men and women differ in perception, communication, self-efficacy, attitude towards success, relationships, and morale is unquestionable (see e.g., Carol Gilligan, Alice Eagly and Linda Carli) and this directly influences how people relate to each other and how they manage relationships in the work environment as well.

According to the 2009 McKinsey Report, women's leadership style, unlike as men's style, is more people-based and can be described as role modeling. It was also stated that women give clear expectations and rewards. Similarly, a study from 2012 prepared by Zenger Folkman demonstrates that women are rated as more competent when taking initiative, self-develop- 
ment, honesty, and driving for results into account.

\section{Source of Gender Differences in Leadership}

Leadership style depends on various factors including education, experience, culture, work experience, and personality, where it is still not clear to what extent it is influenced by gender and other factors. From another perspective, leaders adapt to expectation based on people's categorization of them as male or female (Eagly and Johannesen-Schmidt, 2001). Those expectations are derived from traditional gender roles such as role in the society, in the family and in the organization (Eagly et al., 2000).

According to research by Gita Patel, men and women may have different leadership styles because of variability in the personal sphere. As research proves, in general women are more risk-averse (Weber, Blais, and Betz, 2002), have higher social sensitivity, and react by feeling. When it comes to men, in general they are more overconfident, more optimistic, and react by action. Among other personal differences the most important are confidence, social risk, emotions, and actions.

When it comes to confidence and selfefficacy, men tend to outdo women. In 2001 Barber and Odean found that men trade in greater volumes than women do, therefore were responsible for greater losses (Barber and Odean, 2001). The fact that women are less confident in financial and business matters results in lower levels of profitability. In the case of social risk, even though women are considered to be more risk averse, they tend to take more risks in undertaking social risk than men (Weber, Blais and Betz, 2002)

Another personal difference that may affect leadership style is emotions and actions. According to Harshman and Paivio, women react more emotionally than men do, especially in negative situations. So, when an immediate response is required, men react by action whereas a women's reaction is to feel.

The fact that women in leadership positions are perceived in a different way than men (Carli and Eagly, 2007), may also influence the way they lead due to different expectations. Perception of women managers is, to great extent, affected by stereotypes. In Poland women and girls are assigned the role of maintaining the household, while men and boys are to sustain its financial aspects (Zachorowska-Mazurkiewicz, 2006). Apart from the image of stay-at-home women in Poland, there is a strong confidence in the social mentality and traditional beliefs that women are less effective employee in comparison to men. This image could be influenced by the fact that women have two jobs - a professional one and the one at home - as research demonstrates that woman are, in the majority of cases, the only ones who perform household activities. Moreover, it is believed that women are "naturally" worse leaders, have more difficulties with the decision-making, and are typical predisposed to take care of children, instead of taking care of a company (Balińska, 2007).

It is also believed that woman do not have adequate traits and predispositions to hold high and prestigious positions since they are too emotional, chaotic, and not sufficiently assertive (Balińska, 2007). "People have similar beliefs about leaders and men, but dissimilar beliefs about leaders and women" (Eagly et al., 2001), as women are traditionally seen as caring, people-oriented, warm and nice, while leaders have to be assertive, tough, result-oriented, and confident. This creates a situation in which these two characteristics combined together create a mismatch, resulting in the poorer evaluation of women as leaders.

There is also a visible dichotomy in attitude towards the authoritarian female manager and the authoritarian male manager, where there is more acceptance for men to be authoritarian than for women (Eagly, 2004). When a female chooses an authoritarian style, she is seen as aggressive and her leadership is rejected, as women are stereotypically perceived as the "nice ones." Thus, the autocratic style does not go in line with niceness, again resulting in an unfavorable evaluation.

Therefore, the way women in leadership positions are perceived may influence their effectiveness - when negative performance is expected it may lead to biased evaluation of performance and a negative attitude towards the individual (Eagly, 2008). In reality, acceptance of a leader by subordinates, superiors, and colleagues is crucial to achieving success in leadership. 
Moreover, the fact that women are given more responsibilities (those connected with the upbringing the children and taking care of the household) and the socially accepted stereotypical role of women - far from the leadership position - affects the women themselves, women have fewer opportunities to follow a career path. This deeply embedded archetype of a women-Polish mother affects the situation of women on the labor market. Women employees are seen by the employer as mothers. Therefore, they are perceived as less efficient workers, due to their additional non-paid job, the one at home (Zachorowska-Mazurkiewicz, 2006).

Leadership style may have various sources. Among them are education, work experience, culture, and personal characteristics. Gender is only one of the factors that may or may not affect leadership style.

\section{Methodology}

Secondary and primary data collection methods have been used for the purposes of this study. Secondary data were collected through EBSCO and JSTOR databases As to primary data, the presented research should be perceived as a pilot study, which requires further research due to the small number of respondents and their lack of experience in the management field. In addition to the research itself, an interview has been conducted with an expert on the impact of gender on leadership style Dr. Lidia D. Czarkowska.

The main data gathering technique for this paper was a questionnaire that consisted of three sets of closed questions. It was developed by P.N. Northouse in 2009. A 5-grade Likert scale (with selections ranging from "Not at all" to "Very Much") was used in all twenty-five questions. According to the author of the survey, it was developed to self-recognize one's leadership style and skills and is not limited to leaders. The questionnaire was based on "many empirical studies of leader's skills," including the Katz three skill approach (1955) and the skills model of leadership developed by Mumford (Northouse, 2011).

The aim of the present study was to initiate a discussion on whether there are differences between the leadership styles of men and women. The questionnaire was divided into three parts. The first part evaluates leadership style emphasizing the leader's attitude towards the employee. The second part estimates task versus relationship orientation. The third looks at personal leadership skills. This survey was presented in its original language - English. It was distributed among English-track students majoring in management.

Overall, 120 students completed the survey. An effort was made to ensure an equal representation of men and women so that neither outnumbered the other. Participants were aged from twenty-one to twenty-four and all were majoring in management programs. Thus, despite of the lack of experience, they did possess theoretical knowledge. The fact that students were of similar age and had similar work experience, education, and organizational culture minimized the discrepancies between them. High differences among respondents would make it more difficult to state whether the existing differences in results were due to actual gender differences or other variations. Consequently, lack of the experience in the management field may suggest that identified differences are due to sex differences and are not connected to the ascribed type of leadership or the one imposed by the organization. From another perspective, lack of experience in management forced participants to give hypothetical answers - how they would have behaved in a certain situation - without any actual reflection in reality. Moreover, the fact that respondents were from various countries as well as the fact that the survey was not conducted in their native languages might have had a negative effect on the results. Therefore, this questionnaire should be treated only as initial research for a larger study.

Additionally, a one-on-one interview was conducted with Dr. Lidia D. Czarkowska in order to gain a broader perspective on the issue. The interview was conducted at Koźmiński University in April of 2014. It consisted of three questions and lasted for forty minutes.

\section{Empirical Research}

The survey's main objective was to show differences and similarities in leadership between male and female respondents. The questionnaire was divided into three parts, each focusing on a different issue. Ques- 
tions three to eleven made up the first part that evaluates leadership style with emphasis on the leader's approach to employees. Respondents had to choose the level to which they agreed with the statement, where one stands for "strongly disagree" and five for "strongly agree."

To ascribe a leadership style of authoritarian, democratic, or laissez-faire, the average scores of each respondent were summarized with regard to gender. After running the students t-test, it can be stated that with statistical significance female respondents are more likely to adopt a democratic leadership style $(n=60, p<0.01)$, while in both the authoritarian and laissez-faire styles there was no statistical significance for men and women participants. In support of Hypothesis B, women are more likely to adopt a democratic leadership style compared to men.

Looking at the questions specifically, statistically significant differences were observed in scoring, where out of twentyfive questions, eight were significantly influenced by the gender of the participant with at least a $95 \%$ certainty. In the further analysis, questions that indicated statistical significance $(p<0.05)$ were analyzed, which supports Hypothesis A.

In questions that implied that employees require close supervision, male respondents scored $11 \%$ higher on average than women $(p<0.05)$. This suggests that men more likely prefer close supervision of subordinates than women. In contrast, statements that employees work better when given more freedom resulted in opposite scores. There, the majority of women agreed with the statement as compared with only one-third of men. On average, women allocated higher points in this question by $13 \%(p<0.05)$.

High discrepancies between the genders were observed in questions regarding treatment of rewards and punishments as motivational tools. The majority of women agreed that employees should be given rewards and punishments for the motivational purposes. On average, this was $15 \%$ more likely than in the case of men $(p<0.05)$. Moreover, the majority of female respondents agreed with the statement while over $60 \%$ of men were either neutral or disagreed.

The first part of the questionnaire indicated that male leaders are $10 \%$ less likely to adopt a democratic style of leadership compared to women $(\mathrm{p}<0.05)$.

The second part of the questionnaire analyzed task versus relationship orientation in leadership.

The highest discrepancy as well as highest significance level was observed in statements about preparing a checklist. As a result, women scored $22 \%$ higher than men $(\mathrm{p}<0.01)$. A quarter of all women claimed that they always make a checklist while only $5 \%$ of men claimed to do so. Similarly, female respondents were more likely to prepare a "to-do" list, with a $14 \%$ difference with respect to male results $(\mathrm{p}<0.05)$. When it comes to listening to the special needs of group members, women participants were statistically significantly less likely to do so $(p<0.05)$. As many as $75 \%$ of men claimed to always or often do so compared with only half of the women respondents.

The answers were categorized in order to specify which gender is more task or relationship oriented. On average, women scored 18.33 points out of 25 in task orientation while man only scored 17.22 $(p<0.05)$. When it comes to relationship orientation, male respondents scored 18.72 while female respondents scored one point lower $(\mathrm{p}<0.05)$. Results indicate that female respondents were more likely to be task oriented while male respondents relationship oriented with a level of certainty of $95 \%$. The successive part of the study suggests that Hypotheses C and D are not supported. Moreover, they suggest contradictory results with respect to what can be found in the literature.

The last part of the questionnaire evaluated the personality traits of a leader. This part indicated that women participants are more likely to present more a tolerant and empathetic attitude in comparison to male participants with an average difference of $10 \%(\mathrm{p}<0.05)$.

This initial research study supports Hypothesis A, which states that men and women do lead in different ways.

In order to gain an additional perspective on the topic of gender differences in leadership, an interview was conducted with Dr. Lidia Czarkowska in April of 2014 at Koźmiński University. The interview lasted for forty minutes and consisted of three general questions:

1. Are there differences in the leadership of men and women? 
2. What are the sources of these differences?

3. Can these differences change in line with experience, education, and position?

The interview was conducted in Polish, which is native language of both participants.

According to the interview, there is no clear distinction between male and female leadership as leadership style depends on various factors - education, organization, and experience - while gender is only one of these indicators and is not that much of an influence on leadership style by itself. This is somewhat at odds with the results of the presented study, which indicated statistically significant differences in spheres of leadership style as well as task orientation.

According to Dr. Czarkowska, when evaluating whether there are differences between male and female leaders it is necessary to examine three different levels natural, cultural, and organizational.

The natural level demonstrates that man and women vary, both physically and psychologically. Even the construction of human brain itself indicates such differences. Differences on the natural level are visible through women's ability to focus on multiple things at the same time, for example. Similarly, women handle emotions better and know how to cope with them. Men, for their part, have to learn how to manage, verbalize, and cope with their emotional sphere. Similarly, the study concluded that female respondents were more likely to present a more empathetic and tolerant position. This may suggest that female respondents cope with emotionality more effectively in this regard.

On the cultural level, men and women vary as a result of stereotypes and ascribed roles. Additionally, culture may impact on leadership style in the case of both males and females. In a highly masculine culture, where showing control and achievement is important, both male and female leaders will adopt more masculine characteristics. In a culture where women are traditionally seen as a conflict resolver in the family, they will act similarly in a company, assuming a more relationship-oriented position. Additionally, cultural acceptance of women in higher position and perceptions of women have also turned out to be influential in adopted leadership style.
Similarly, on the organizational level, leaders often adapt their style to the culture that is presented within the company.

In this regard, the pilot study has shown that female respondents are focused more on the realization of the task, while male participants are intent on keeping up the relationship. This is contradictive of the Polish tradition of women, who should take care of relationships within the family (Zachorowska-Mazurkiewicz, 2006).

The conducted survey shows that female respondents are more likely to adopt a democratic leadership style. This corresponds to Dr. Eagly's research from the 1980s, 1990s, and 2000s and supports Hypothesis B. The survey also proved that female respondents treat punishments and rewards as a motivational tool, which matches McKinsey research from 2009.

When it comes to relationship versus task orientation, the presented study indicated results opposite those of Dr. Eagly, which stated that women tend to be more relationship oriented while men task oriented. Thus, the results where the reverse of the initial Hypotheses C and D. The difference between results was substantial. On the other hand, however, relationship-oriented male respondents stated that employees work better under pressure and must be constantly supervised and monitored, which are not indicators of a relationship orientation. On the contradictive side, task-oriented female participants, gave their employees more freedom and, what is important, scored substantially higher when it comes to showing tolerance and empathy, which would be associated more likely with relationship rather than task orientation. In her report, Dr. Alice Eagly showed that women put more emphasis on communication, affiliation, and cooperation than men. However, the pilot study presented the exact opposite view. Male respondents listen to the special needs of group members significantly more often, while women focus on completion of the task, which is contradictive to the Hypotheses C and D. When it comes to communication skills, the presented study did not indicate any differences between male and female scores. This is in spite of that fact that in literature it can be found that women communicate more effectively. According to Dr. Czarkowska, the difference between the current pilot study and 
Dr. Alice Eagly's research from the 1990s may vary in relationship and task orientation, as women's position in companies has changed over the last twenty years. In line with the interview, women may become more task oriented due to the fact that they want to prove to be leaders that are as good leader as men. Thus, they put more focus on the achievement of the task. The fact that women have to find a balance between their private and professional lives may also indicate why women became more focused on task completion.

These results may be interpreted as women having to meet higher standards than men to attain leadership roles. Therefore, they have to maintain better performance to retain their position and cannot afford the risk of a passive or laissez-faire leadership style (Eagly and Johannesen-Schmidt, 2001).

\section{Conclusions}

The underrepresentation of women in managerial positions reflects a wasted opportunity to benefit from the capabilities of the best potential candidates, male or female.

The current study concludes that this underrepresentation is not the evidence of a less adequate leadership style on the part of women. Firstly, gender is not the dominant factor in leadership style and secondly, previous and current research indicates that women are more likely to adopt a democratic style than men, while at the same time being more tolerant and understanding.

Leadership is affected by various variables where gender may be one of them, influencing style and orientation, but also relations, perceptions, and expectations from the subordinate side towards the leader. Due to stereotypes and biases, women leaders are perceived and evaluated in a different way than men in the same positions. Cultural, organizational, and personality factors influence the way men and women behave in leadership positions and the style they adopt.

Literature and the current study suggest that leadership may be influenced by gender, supporting the Hypothesis A, where women act in more supportive ways giving subordinates more freedom, less supervision, and are more understating and tolerant. Moreover, they treat rewards as motivational tool and organize work through lists

In support of Hypothesis B, the study indicated that men and women do adopt different leadership style. Women tend to be more democratic when holding leadership positions. This corresponds with Dr. Eagly's research from the 1980s, 1990s, and 2000s. Moreover, women are less likely to adopt an authoritarian leadership style than man. This is because of the lower level of acceptance for autocratic women than autocratic men from the subordinate side.

Hypotheses C and D, which indicated that men tend to be more task oriented, while women relationship oriented accordingly, were not confirmed. In fact, the study presents contrary results. This indicates that women are more likely to be task oriented while men are relationship oriented. Results are contradictory. Task oriented women are still more likely to act in more empathetic and tolerant way than relationship-oriented men.

These results should be perceived as a pilot study due to the fact that respondents were not experienced leaders. Results might vary for actual leaders and managers. Further research on managers would present more realistic results and would answer questions regarding the extent to which men and women lead in different ways and what are the sources of these probable differences. Further research should be conducted on leaders, preferably from the same organization and with similar work experience in order to minimize differences that may also be indicators of the adopted style of leadership.

\section{References}

Andersen, J.A. and Hansson, P.H. (2011). At the End of the Road? On Differences between Women and Men in Leadership Behavior. Leadership and Organizational Development Journal, 32(5), 428-441.

Barber, B.M. and Odean, T. (2001). Boys Will Be Boys: Gender, Overconfidence, and Common Stock Investment. The Quarterly Journal of Economics, 116(1), 261-292.

Becker, S.W. and Eagly, A.H. (2004). The Heroism of Women and Men. American Psychologist, 69.

Chemers, M.M. (1997). An Integrative Theory of Leadership. USA: Lawrence Erlbaum Associates. 
Eagly, A. and Carli, L. (2007). Through the Labyrinth: The Truth on How Women Become Leaders. Center for Public Leadership, USA.

Eagly, A.H. and Johannesen-Schmidt, M.C. (2001). The Leadership Styles of Women and Men. Journal of Social Issues, 57(4).

Eagly, A.H., Wood, W. and Diekman, A.B. (2000) Social role theory of sex differences and similarities: A current appraisal. In: T. Eckes and H.M Trautner (eds.), The developmental social psychology of gender (pp. 123-174). Mahwah, New Jersey: Erlbaum.

European Commission (2013). The Current Situation of Gender Equality in Denmark: Country Profile. Assessed at http://ec.europa.eu/justice/ gender-equality/files/epo_campaign/131203_country-profile_denmark.pdf.

Forbes (2013). Assessed at http://kariera.forbes.pl/wpolsce-tylko-10-5-proc-kierowniczych-stanowiskzajmuja-kobiety,artykuly,166922,1,1.html.

Główny Urząd Statystyczny (2012). Kobiety i męż czyźni na rynku pracy [Men and women on the labor market]. Assessed at http://www.stat.gov.pl/ $\mathrm{cps} / \mathrm{rde} / \mathrm{xbcr} / \mathrm{gus} / \mathrm{f}$ _kobiety_i_mezczyzni_na rynku pracy_2012.pdf.

Heilman, M.E. and Eagly, A.H. (2008). Gender Stereotypes Are Alive, Well and Busy Producing Workplace Discrimination. Industrial and Organizational Psychology, 1.

Kanter, R.M. (1977). Men and Women of the Corporation. New York: Basic.

Kent, T.W. and Schuele, U. (2010). Gender Differences and Transformational Leadership Behavior: Do Both German Men and Women Lead in the Same Way? International Journal of Leadership Studies, 6(1), 52-56.

Kirkpatrick, S.A. and Locke, E.A. (1991). Leadership: Do Traits Matter. Academy of Management Executive, 5(2).
Kirkpatrick, S.A. and Locke, E.A. (1991). Leadership: Do Traits Matter? Academy of Management Executive, 5(2).

Kupczyk, T. (2009). Kobiety $w$ zarzadzaniu $i$ czynniki ich sukcesów [Women in management and factors of their success]. Wrocław: Wyższa Szkoła Handlowa.

Lewin, K. (1939). Patterns of Aggressive Behavior in Experimentally Created Social Climates. Journal of Social Psychology, 10, 271-301.

McKinsey and Company (2009). Women Leaders: A Competitive Edge in and After the Crisis. Assessed at http://www.mckinsey.com/ /media/ McKinsey/Business\%20Functions/Organization/ Our\%20Insights/Women\%20matter/Women_matter_dec2009_english.ashx.

Northouse, P. (2011). Introduction to Leadership, Concepts and Practices. Sage Publications, Inc.

Patel, G. (2013). Gender Differences in Leadership Styles and the Impact Within Corporate Boards. The Commonwealth Secretariat, Social Transformation Programs Division.

Stogdill, R.M. (1948). Personal Factors Associated with Leadership. Journal of Psychology, 25, 35-71.

Usman, E. and Usman, A. (2016). Leadership Styles in Budgeting Participation to Support Managerial Performance. The International Journal of Organizational Innovation, 8

Vinnicombe, S. and Kakabadse, A. (1999). The Debate: Do Men and Woman Have Differen Leadership Styles? Management Focus Issue, 12.

Weber, E.U., Blais, A. and Betz, E.N. (2002) A Domain Specific Risk-Attitude Scale: Measuring Risk Perceptions and Risk Behaviors. Journal of Behavioral Decision Making, 15.

Zachorowska-Mazurkiewicz, A. (2006). Kobiety $i$ instytucje [Women and institutions]. Śląskie Wydawnictwo Naukowe. 